\title{
学会賞 奨励賞受賞記念
}

\section{日本比較内分泌学会奨励賞を受賞して 鳥類の視床下部に存在する神経ペプチドの探索と生理機構に関する研究}

浮穴 和義 (広島大学大学院総合科学研究科)

E-mail: ukena@hiroshima-u.ac.jp

この度、鳥類の視床下部に存在する神経ペプチドの 探索と生理機能に関する研究」というタイトルで平成 28 年度日本比較内分泌学会奨励賞を受賞することができま した。ご推薦並びに選考の労を取っていただいた先生方 に心より御礼申し上げます。さらに博士後期課程及び助 手時代の指導教授の筒井和義先生を始め、これまでの共 同研究者の先生方、学生の方々に重亦て感謝申し上げま す。筒井先生の小林賞受賞と同じタイミングでの奨励賞 受賞となり、この上ない喜びを感じています。

この受賞の機会にこれまでの私の研究を振り返ってみ たいと思います。卒業研究から博士前期課程においては 広島大学理学部で松島治教授のご指導の下、環形動物か らの生理活性ペプチドの探索と生理機能解析を行いまし た。その過程において、ミミズから単離したオキシト シン系ペプチド (アネトシン) を注射すると産卵行動が 直ちに引き起こされることを目の当たりにし ${ }^{1)}$ 、神経ペ プチド/ペプチドホルモンにより我々の行動が制御され ているという概念がインプリントされた瞬間となりまし た。その後、博士後期課程から筒井先生の研究室に移り、 神経ステロイドの研究で学位を取得し ${ }^{2,3)}$ 、助手時代は GnIH研究にも参画することができました ${ }^{4)}$ 。2006年に 筒井先生が早稲田大に転出された後は、ホヤからのオ キシトシン系ペプチドや鳥類からの 26RFamideペプチ ドの同定とその機能解析を行ってきました ${ }^{5,6)}$ 。この間、 ペプチド性因子の遺伝子発現、構造解析、形態学的解析、 生理機能解析を比較生物学的視点から多角的に解析する ということを意識しながら研究を進めることができまし た。また、生殖内分泌調節、水・電解質代謝調節、摂食 . エネルギー代謝調節など様々な内分泌現象の解明へ取り 組むことができたのも、幸運であったと感じています。

これらの研究過程で、鳥類の視床下部には未知の神 経ペプチドが存在していると考元、それを見つけたいと 思うようになりました。多くの失敗を経験した後、漸く 候補物質をコードする遺伝子を見出すことができました 7)。ただ、予想したペプチドは当初考えていたよりも長 鎖ペプチドであり、「合成できない、溶けない、効かない」 という問題が生じ、数年間、全くデー夕や論文が出ない 時期を経験しました。様々なペプチド合成法の試みの後、 コンスタントにペプチド産出が可能となり ${ }^{8 \sim 10)}$ 、少しず つですが生理機能解析の実験を行うことができるように なりました。この新しく見出した脳内因子は、Neurosecretory Protein GL (NPGL) と命名した 80 アミノ酸残基か らなる小タンパク質ですが、これまで知られているどの
ペプチドファミリーにも属さない新規の脳内因子です7)。 現在、ニワトリ、ラット、マウスなどを用いて研究を進 めていますが、摂食行動やエネルギー代謝調節に関わつ ていることを示すデー夕を得ています ${ }^{11,12)}$ 。NPGLをコ ードする遺伝子は円口類にも存在することから、脊椎動 物において重要な働きをしているのではないかと予想し ており、今後もNPGLの構造と作用の普遍性と多様性を 比較内分泌学的観点から研究を展開していきたいと考元 ています。まだまだ発展途上の研究でありますが、文字 通り奨励賞ということで、今後の研究に弾みが付く受賞 となったことは間違いありません。

一方、私が比較内分泌学会関係の大会にいつから参加 するようになったのだろうかと、過去の予稿集や記録を 見返してみました。初参加は、1996年1月にオースト ラリアで開催された第3回アジア・オセアニア比較内分 泌学会議でした。これは博士前期課程の修了直前で、初 めての国際会議・海外経験でもありましたが、昨日の事 のように思い出します。その後、博士後期課程時代に第 22 回能登大会に参加して以来、約 20 年間、継続して研 究発表を行ってきました。さらに、学会ニュース編集や 第33回及び第 40 回広島大会の事務局長も務めさせてい ただき、貴重な経験をさせていただきました。また、こ の受賞記を記すに当たり、学会ホームページ上の小林英 司先生の比較内分泌学の定義や比較内分泌ニュース No. 114 (2004) の学会設立30周年特別寄稿なぞを改めて纬 読させていただきました。学会設立から国内・国際大会 の開催、さらには様々な図書出版など、非常に幅広い学 会活動に関し、大勢の先生方のご尽力の足跡を感じるこ とができました。そのような歴史と伝統の延長線上を私 は歩かせていただいていることを再認識し身の引き締ま る思いがしました。新規脳内因子NPGLが系統発生学 的に構造と機能をどのように変化あるいは維持してきた のかを解析する事が私の今後の縦糸であるとすれば、比 較内分泌学の歴史と伝統を横糸として利用し、どのよう な織物を編めるのか、また、編んでいく必要があるのか を考える良い機会となりました。年齢的にはもはや若手 ではなく中堅であり、比較内分泌学のフィールドで仕事 ができる折り返し地点に立っているように思います。今 回の受賞の喜びと感謝の気持ちを常に忘れず、今後も研 究と学会発展のために微力ですが努力していきたいと考 えています。引き続き、ご指導ご鞭撻のほど、宜しくお 願い申し上げます。 


\section{文献}

1 ) Oumi T, et al. J Exp Zool, 276, 151-156 (1996).

2 ) Ukena K, et al. Endocrinology, 139, 137-147 (1998).

3 ) Ukena K, et al. Endocrinology, 140, 805-813 (1999).

4 ) Ukena K, Tsutsui K. Mass Spectrom Rev, 24, 469-486 (2005).

5 ) Ukena K, et al. Endocrinology, 149, 5254-5261 (2008).

6 ) Ukena K, et al. Endocrinology, 151, 2255-2264 (2010).
7 ) Ukena K, et al. Biochem Biophys Res Commun, 446, 298303 (2014).

8 ) Masuda K, et al. J Pept Sci, 21, 454-460 (2015).

9 ) Masuda K, et al. FEBS Open Bio, 5, 844-851 (2015).

10) Masuda K, et al. Tetrahedron Lett, 57, 804-807 (2016).

11) Matsuura D, et al. Endocrinology, 158, 1120-1129 (2017).

12) Shikano K, et al. Gen Comp Endocrinol, (2017) in press. 